\title{
The Influence of Lecturer Service Quality, Family Support, Facilities and Infrastructure Availability, and Student Learning Motivation on Indonesian Nurse Competency Test Results
}

\author{
Andro Ruben Runtu, Fientje J.A. Oentoe, Herry Sumual, Beatrix J. Podung \\ Bethesda Nursing Academy, Tomohon, North Sulawesi, Indonesia ${ }^{1}$ \\ Manado State University, Manado, North Sulawesi, Indonesia \\ Email: androruntu21@gmail.com, fientjeoentoe@unima.ac.id, herrysumual@unima.ac.id, \\ beatrixpodung@unima.ac.id
}

\section{ARTICLE INFO}

Received: 08-01-2022

Revision: 13-01-2022

Received : 18-01-2022

Keywords:

Lecturer service

quality; family

support; availability of

facilities and learning

infrastructure;

learning motivation;

competency test

results nurses

\section{ABSTRACT}

The research analyzing the competency test for nurses is of particular concern for nursing education because incompetent nursing professions could not be registered as nurses in Indonesia. The purpose of this study was to determine the effect of lecturer service quality, family support, availability of learning facilities and infrastructure, and student learning motivation on the results of the Indonesian Nurses Competency Test (INCT). The research method used is quantitative research design with the Simple Random Sampling technique. The research sample was 100 respondents from the nursing profession graduates. Data collection by questionnaire, descriptive data analysis percentage, and regression test. The results of the study showed that there was an effect of the quality of lecturer services on the results of INCT (0.024), family support on the results of INCT (0.032), the availability of learning facilities and infrastructure on the results of INCT (0.015) and learning motivation on the results of INCT (0.030). Simultaneously, there is an effect of the quality of lecturer services, family support, availability of learning facilities and infrastructure, and learning motivation on the results of INCT (0.000), adjusted $\mathrm{R} \neg$ Square test with a percentage of $77.1 \%$ of the variables of INCT results can be explained by the four variables. These results can be used as evaluations and policies for interested parties in improving the achievement of INCT graduation results, which are also a benchmark for implementing and quality assurance in higher education.

\section{Introduction}

Education is very influential in the development of human civilization, as social beings, humans have potency since birth and must be developed and directed continuously. The development of this human potency requires guidance and direction through education (Fadli \& Faddila, 2020). education will produce a generation that has quality human resources to be able to build the nation and state towards a prosperous direction for all members of society fairly and equitably from the center to remote areas. For this reason, management of education administration must be carried out evenly, fairly, tiered and well organized (Sutrisno, 2013).

INCT is also one of the stages to give a decision to grant licenses to nurses (Rohimah \& Amaliya, 2016), which includes knowledge,

\footnotetext{
How To Cite:

Runtu, A. R., et. al., (2022) The Influence of Lecturer Service Quality, Family Support, Facilities and Infrastructure Availability, and Student Learning Motivation on Indonesian Nurse Competency Test Results. Journal of Social Science. 3(1). https://doi.org/10.46799/jss.v3i1.277

E-Issn: 2721-5202

Published By: $\quad$ Ridwan Institut
} 
skills and attitudes in completing tasks according to established standards, in the form of a Registration Certificate (Mushoffa, n.d.).

Learning activities are a complex process, so that students can easily understand and digest learning materials, so lecturers must be creative and innovative in using learning models and learning tools (Hanafi, Mansur, \& Hufron, 2020). Supported by the correct understanding of the curriculum and adequate learning facilities and good learning motivation, it will make it easier for lecturers to explain lecture materials and will facilitate understanding for students (Pramudyo, 2010).

Parental support is also involved in a learning process. According to Handayani (2012), family support is one of the efforts in the family in overcoming problems that arise. Family support can also be in the form of emotional and informational support, where the family is a good motivator for children and families.

In improving the results of the nurse's competency test, it must be supported by the availability of learning facilities provided by universities, of course, it can be a tool that can be used in teaching and learning activities and also makes students more active and easy to learn all the lessons given by the lecturer (Aprilia, 2008). In the Indonesian Ministry of Health (2010), regarding laboratory learning climate management, the availability of inadequate learning facilities and infrastructure will make it difficult for a lecturer to meet the target of achieving competency standards.

Student learning motivation also has an important role in the learning process, both for lecturers and students. One of the efforts is to improve the quality of nursing graduates by holding the Indonesian Nurses Competency Test (INCT).

Based on national data, the results of passing the Indonesian Nurses Competency Test (INCT) throughout Indonesia have not met expectations. Nationally, the INCT graduation rate in 2018 was declared competent at 46\%, in $201950.92 \%$ was declared competent, and in 2020 it only reached $50.81 \%$ INCT graduation. INCT data at the Faculty of Medicine (FK) of the Nursing Science Study Program (PSIK) at Sam Ratulangi University Manado in 2018 which were declared to have passed the UKOM as many as $35.3 \%$, in 2019 as many as $51.72 \%$ and in 2020 as many as $51.25 \%$ (Kemendikbud, 2021).

Based on the data above, the results of the nurse's competency test at nursing program Sam Ratulangi University Manado are very low than expectations that all test takers should pass all or be $100 \%$ competent. A low pass percentage can have a negative impact on institution's reputation and students, so changes are needed for the better. Researchers conducted interviews with INCT participants who had not yet passed, where they needed special attention by the institution, because it would have an impact on the quality of graduates who would be judged incompetent as nurses, and the quality of higher education could be doubted by the public.

Here we need an active role from all parties, lecturer services (having a role with abilities in learning quality, item development and review items, and guidance), high family support, availability of learning facilities and infrastructure that support learning, as well as student learning motivation must be improved (W, 2017); (Lukmanulhakim \& Puspitorini, 2018).

Based on the description of the phenomenon above, the authors conducted a study "The Influence of Lecturer Service Quality, Family Support, Availability of Learning Facilities and Infrastructure, and Student Learning Motivation on the Results of the Indonesian Nurses Competency Test (INCT) at Nursing Science Study Program Sam Ratulangi University Manado".

\section{Method}

This study uses a quantitative research design and a survey approach, with a Simple Random Sampling technique. Conducted at Nursing Science Study Program at Sam Ratulangi University Manado from January 2021 to August 2021. The samples were 100 graduates of the Nursing Science Study Program Nurse profession at Sam Ratulangi University Manado.

The data were analyzed in several stages, namely editing, coding, entry, cleaning and tabulating, descriptive analysis and regression testing. 


\section{Results And Discussion Data Description}

Table 1

Variable Frequency Distribution of INCT Results

\begin{tabular}{llc}
\hline Category & Total & Percentage \\
\hline Competent & 10 & $10 \%$ \\
In competent & 90 & $90 \%$ \\
\hline Total & $\mathbf{1 0 0}$ & $\mathbf{1 0 0} \%$ \\
\hline \multicolumn{2}{r}{ Source: Primary } & Data, 2021
\end{tabular}

The results of the study obtained that at most 90 respondents $(90 \%)$ were competent on the results of the INCT, and 10 respondents $(10 \%)$ were not competent on the results of the INCT.

Table 2

Frequency Distribution of Lecturer Service Quality Variables

\begin{tabular}{lcl}
\hline Category & Total & Percentage \\
Very High & 28 & $28 \%$ \\
High & 51 & $51 \%$ \\
Moderate & 21 & $21 \%$ \\
\hline Total & $\mathbf{1 0 0}$ & $\mathbf{1 0 0} \%$ \\
\hline \multicolumn{2}{l}{ Source: Primary Data, 2021}
\end{tabular}

The results obtained showed that $28 \%$ of respondents answered very high lecturer service quality, $51 \%$ of respondents answered lecturer service quality, and $21 \%$ of respondents answered sufficient lecturer service quality. Thus, lecturer service quality for INCT was high.

\begin{tabular}{lcc}
\multicolumn{2}{c}{$\begin{array}{c}\text { Tabel } \mathbf{3} \\
\text { Frequency Distribution of Family } \\
\text { Support Variables }\end{array}$} \\
\hline Category & Total & Percentage \\
Very High & 33 & $33 \%$ \\
High & 49 & $49 \%$ \\
Moderate & 18 & $18 \%$ \\
\hline Total & $\mathbf{1 0 0}$ & $\mathbf{1 0 0 \%}$ \\
\hline \multicolumn{3}{c}{}
\end{tabular}

The results obtained showed that as many as $33 \%$ of respondents answered very high family support, $49 \%$ of respondents answered high family support, and $18 \%$ of respondents answered sufficient family support. It was concluded that family support for INCT results was high.
Tabel 4

Variable Frequency Distribution Availability of Learning Facilities and Infrastructure

\begin{tabular}{lll}
\hline Category & Total & Percentage \\
Very High & 28 & $28 \%$ \\
High & 50 & $50 \%$ \\
Moderate & 22 & $22 \%$ \\
\hline Total & $\mathbf{1 0 0}$ & $\mathbf{1 0 0} \%$ \\
\hline \multicolumn{3}{l}{ Source: Primary Data, 2021 }
\end{tabular}

The results obtained showed that as many as $28 \%$ of respondents answered that the availability of learning facilities and infrastructure was very high, $50 \%$ of respondents answered that the availability of learning facilities and infrastructure was high, and infrastructure was quite $22 \%$. It was concluded that the availability of learning facilities and infrastructure was high.

Tabel 5

Frequency Distribution of Student Learning Motivation Variables

\begin{tabular}{lll}
\hline Category & Total & Percentage \\
Very High & 27 & $27 \%$ \\
High & 48 & $48 \%$ \\
Moderate & 25 & $25 \%$ \\
\hline Total & $\mathbf{1 0 0}$ & $\mathbf{1 0 0} \%$ \\
\hline \multicolumn{3}{l}{ Source: Primary Data, 2021 }
\end{tabular}

The results obtained showed that $27 \%$ of respondents answered very high learning motivation, $48 \%$ of respondents answered high learning motivation, and $25 \%$ of respondents answered sufficient learning motivation, so that student learning motivation was high.

\section{Hypotheses Testing}

1) The significant effect of the Lecturer Service Quality variable (X1) on the INCT results $(\mathrm{Y})$.

The result of tcount $=2,229$ and the value of Sig. $=0.024$, which means that there is a positive and significant influence on the Quality of Lecturer Service on the results of INCT. The influence of the Lecturer Service Quality variable on the INCT results, namely the result of the square of $R$ is 0.704 . This means that the influence of the Lecturer Service Quality variable (X1) on the INCT result variable is 
$70.4 \%$ and the rest is influenced by other variables.

2) The effect of the family support variable (X2) on the INCT results $(\mathrm{Y})$.

The result of tcount $=2.182$ and the value of Sig. $=0.032$, which means that there is a positive and significant effect of Family Support on the INCT results. The influence of the Family Support variable on the INCT results, namely the result of the square of $R$ is 0.654 . This means that the influence of the Family Support (X2) variable on the INCT result variable is $65.4 \%$ and the rest is influenced by other variables.

3) The effect of the variable Availability of Learning Facilities and Infrastructure (X3) on the results of INCT (Y).

The result of tcount $=2.474$ and the value of Sig. $=0.015$, which means that there is a positive and significant influence on the Availability of Learning Facilities and Infrastructure on the results of INCT. The magnitude of the influence of the Availability of Learning Facilities and Infrastructure variables on the INCT results, namely the result of the square of $R$ is 0.652 . This means that the effect of the variable Availability of Learning Facilities and Infrastructure (X3) on the INCT result variable is $65.2 \%$ and the rest is influenced by other variables.

4) The influence of student learning motivation variable (X4) on the results of INCT.

The result of tcount $=2.206$ and the value of Sig. $=0.030$, which means that there is a positive and significant influence on Student Learning Motivation on the results of INCT. The large influence of the Student Learning Motivation variable on the results of INCT is called the coefficient of determination, namely the result of the square of $R$ which is 0.700 . This means that the effect of the Student Learning Motivation variable (X4) on the INCT result variable is $70 \%$ and the rest is influenced by other variables.

Based on the F-test table obtained Fcount $=84,234$ and the value of sig. $0.000<0.05$ and Ftable (df1 = 1; df2 = 3.940), then Fcount > Ftable, so this regression model can be used to draw conclusions. Furthermore, it can be seen that the regression equation for the data pair quality of lecturer services, family support, availability of learning facilities and infrastructure and student learning motivation on INCT results is significant. Therefore the regression equation, $\hat{Y}=34.888+0.064 X 1+0.051 X 2+0.053$ $\mathrm{X} 3+0.280 \mathrm{X} 4$

Can be used to explain the joint influence of the quality of lecturer services, family support, availability of learning facilities and infrastructure and student learning motivation on INCT results. The higher the quality of lecturer services, family support, availability of learning facilities and infrastructure and student learning motivation, the greater the influence on the results of the Indonesian Nurses Competency Examination (INCT).

In the table of the coefficient of simultaneous determination or Adjusted Rsquare, the total contribution of the quality of lecturer services, family support, availability of learning facilities and infrastructure and student learning motivation to the INCT results is 0.771 or $77.1 \%$

\section{Results}

1) The Influence of Lecturer Service Quality on INCT Results

The results of hypothesis testing state that there is a positive and significant influence between the Quality of Lecturer Service on INCT Results at Nursing Science Study Program Sam Ratulangi University Manado. This means that the higher the quality of Lecturer Services, the higher the INCT results. On the other hand, if the quality of the lecturer's services is getting lower, the results of the INCT will also be lower. The research results are in line with what was obtained by Choeron (2020), it was found that there was a positive and significant effect of intensive tutoring, which proved to be effective, very important to be given to students in readiness to face the competency test (UKOM) so that the UKM graduation rate could increase. The results of this study are also supported by research conducted by (Dewi, 2017) where the service quality partially has a positive effect on the quality of education (quality education) and the ability of 
lecturers. The results of the research are supported by a strong influence on the process of implementing lectures and exams, facilities, competencies possessed by lecturers, lecturers' attitudes, and ways of delivering material.

2) The Effect of Family Support on INCT Outcomes

The results of hypothesis testing state that there is a positive and significant effect between Family Support on INCT Outcomes at PSIK, Sam Ratulangi University, Manado. This means that the higher the family support, the higher the INCT result. On the other hand, if family support is lower, the INCT result will be lower. The results of this study are in line with research by Nurkholis (2006), that family support can be realized in the form of love, economy, giving advice and so on.

3) The Influence of Availability of Learning Facilities and Infrastructure on INCT Outcomes

The results of hypothesis testing state that there is a positive and significant influence between the Availability of Learning Facilities and Infrastructure on INCT Outcomes at Nursing Science Study Program Sam Ratulangi University Manado. This means that the higher the availability of learning facilities and infrastructure, the higher the INCT results. On the other hand, if the availability of learning facilities and infrastructure is lower, the INCT results will be lower.

This research is supported by the research of Krisdianto and Kusumawati, (2019), which proved that the availability of learning facilities and infrastructure is one of the factors determining the success (Pratiwi, 2020) of INCT, the more complete the facilities and infrastructure lead to high INCT results. Facilities and infrastructure used for competency test such as nursing laboratories, computer laboratories and libraries must be equipped so that students can gain knowledge more easily. If the availability of adequate and complete learning facilities and infrastructure will affect the results of the INCT.

4) The Influence of Student Learning Motivation on INCT Results
The results of hypothesis testing state that there is a positive and significant effect between Student Learning Motivation on UK Outcomes at PSIK, Sam Ratulangi University, Manado. This means that the higher the student's learning motivation, the higher the INCT's results. On the other hand, if the student's motivation to learn is lower, the INCT's results will be lower.

The results of this study are supported by Nofia Frisca (2017), student motivation is a factor that affects the graduation of Nursing Profession students in UKOM. Learning motivation is prioritized by the students themselves, interest arises without coercion. Students are expected to increase their understanding of the nurse's competency test.

5) The Influence of Lecturer Service Quality, Family Support, Availability of Learning Facilities and Infrastructure and Student Learning Motivation on INCT Results.

The results of hypothesis testing showed that together there is a significant influence between Lecturer Service Quality, Family Support, Availability of Learning Facilities and Infrastructure and Student Learning Motivation on INCT Outcomes at Nursing Science Study Program Sam Ratulangi University Manado with a value of Sig. $0.000<0.05$. This means that the higher the Quality of Lecturer Services, Family Support, Availability of Learning Facilities and Infrastructure and Student Learning Motivation, the higher the INCT results. On the other hand, if the Quality of Lecturer Services, Family Support, Availability of Learning Facilities and Infrastructure and Student Learning Motivation are lower, the INCT results will also be lower.

The results of this study explain that to produce a good INCT, it can be built through improving the quality of lecturer services, family support, the availability of learning facilities and infrastructure and also learning motivation from students themselves.

The nurse's competency test is the process of measuring knowledge, skills of students at nursing colleges (Potter \& Perry, 2010), if declared competent will be given a Registration Certificate (STR) 
which is a legality in work, this is also a challenge for the quality of a university (Silvestri, 2016).

The high quality of lecturer services is believed to have a potential positive influence for lecturers to serve their students. Strong motivation will not only have an impact on the relationship between lecturers and students in the academic field (Mawaddah, 2020), but also psychologically will affect the interest, attention, perception, and even the character of students after graduation. Students who have been served well by their lecturers tend to have good attention and motivation if they later serve others in connection with their duties (Setyoningtyas, 2017).

The family is the main education center and the first (Putri, 2018). Parents should pay more attention to the education and development of their children's learning, affection, attention or appreciation (Allen \& Friedman, 2010), so that it will lead to a good mentality for children.

The availability of facilities and infrastructure for students to support the competency test (Sukarni, 2018), is the availability of books in the library, computer laboratory and nursing laboratory for practicum.

In getting the INCT results that are in line with expectations, it is necessary to have very high motivation (Saeed,S \& Zyngier, 2012). within the students themselves so that their achievements and learning outcomes can be optimal.

\section{Conclusion}

Based on the results of research and hypothesis testing, it conclude several things such as;

There is a positive and significant influence between the quality of lecturer services on the INCT results at the Nursing Science Study Program at Sam Ratulangi University Manado.

Family support has a positive and significant effect on INCT results at Nursing Science Study Program Sam Ratulangi University, Manado.

There is a positive and significant influence between learning facilities and infrastructure available on the INCT results at the Nursing Science Study Program Sam Ratulangi University Manado.

There is a positive and significant influence between student learning motivation on INCT results at Nursing Science Study Program at Sam Ratulangi University, Manado.

Quality of Lecturer Service, Family Support, Availability of Learning Facilities and Infrastructure, and Student Learning Motivation together have a significant effect on INCT Results at Nursing Science Study Program at Sam Ratulangi University Manado.

\section{References}

Allen, Karen Neuman, \& Friedman, Bruce D. (2010). Affective learning: A taxonomy for teaching social work values. Journal of Social Work Values and Ethics, 72), 1-12. Google Scholar

Aprilia, Adriana. (2008). Pengaruh Lecturer performance dan service quality terhadap quality education untuk meningkatkan student satisfaction. Jurnal Manajemen Perhotelan, 4(2), 5866. Google Scholar

Dewi, Ariya Purnamasari. (2017). Pengaruh Kinerja Dosen Dan Kualitas Layanan Terhadap Kualitas Pendidikan Dan Kepuasan Mahasiswa Fakultas Teknik Universitas Muhammadiyah Jakarta. Prosiding Semnastek. Google Scholar

Fadli, Uus Mohammad Darul, \& Faddila, Syifa Pramudita. (2020). Pengaruh Lingkungan Kerja, Kompetensi Dosen, Dan Kualitas Layanan Terhadap Citra Perguruan Tinggi. Jurnal Manajemen \& Bisnis Kreatif, 6(1), 72-80. Google Scholar

Hanafi, Roy, Mansur, Muhammad, \& Hufron, M. (2020). Pengaruh Kualitas Pelayanan Dosen Dan Fasilitas Perkuliahan Terhadap Kepuasan Mahasiswa Fakultas Ekonomi Dan Bisnis Universitas Islam Malang. Jurnal IImiah Riset Manajemen, 9(06). Google Scholar

Kemendikbud. (2021). Hasil Uji Komperensi Ners tahun 2019 dan 2020. Jakarta.

Krisdianto, Muhammad Agung, \& 
Kusumawati, Wiwik. (2019). FaktorFaktor Yang Mempengaruhi Kelulusan Uji Kompetensi Ners Indonesia (UKNI). The Indonesian Journal of Health Science, 11(1), 1-8. Google Scholar

Lukmanulhakim, \& Puspitorini, L. (2018). Analisis faktor yang mempengaruhi capaian kelulusan uji kompetensi ners Indonesia Program Profesi Ners. Jurnal Cakrawala Pendidikan, 306-320.

Mawaddah, Armi. (2020). Dukungan dan motivasi ketua jurusan dan dosen dalam pelaksanaan uji kompetensi mahasiswa keperawatan. Google Scholar

Mushoffa, Muna. (n.d.). Sumber stres dan mekanisme koping mahasiswa ilmu keperawatan UIN Syarif Hidayatullah Jakarta dalam pembelajaran klinik. UIN Syarif Hidayatullah Jakarta: Fakultas Kedokteran dan Ilmu Kesehatan, 2017. Google Scholar

Nofia Frisca. (2017). Faktor-faktor yang berhubungan dengan kelulusan mahasiswa profesi ners dalam uji kompetensi di stikes perintis padang kampus II bukittinggi tahun 2017. STIKes PERINTIS PADANG. Google Scholar

Pramudyo, Anung. (2010). Analisis faktorfaktor yang mempengaruhi kinerja dosen negeri pada kopertis Wilayah $\mathrm{V}$ Yogyakarta. JBTI: Jurnal Bisnis: Teori Dan Implementasi, 1(1), 1-11. Google Scholar

Pratiwi, B. M. (2020). Pengaruh Fasilitas Belajar Dan Motivasi Belajar Terhadap
Prestasi Belajar Siswa Smk Model Pgri 1

Mejayan. Jurnal FIPA. Google Scholar

Putri, R. A. (2018). Hubungan antara Persepsi terhadap Dukungan Sosial Orangtua dengan Penyesuaian Diri dalam Penyusunan Skripsi pada Mahasiswa Fakultas Psikologi Universitas Diponegoro. Google Scholar

Rohimah, Annisa'I, \& Amaliya, Mida Ayu. (2016). Taktis Uji Kompetensi Keperawatan Ners. Jakarta. Edu Penguin. Google Scholar

Silvestri, L. H. (2016). Saunders 360 Review Untuk Uji Kompetensi Ners Indonesia (UKNI). Singapore: Elsevier Singapore.

Sukarni, Sukarni. (2018). Kontribusi pembelajaran disiplin belajar, fasilitas belajar di rumah, dan perhatian orang tua terhadap prestasi siswa ilmu pengetahuan alam. Wiyata Dharma: Jurnal Penelitian Dan Evaluasi Pendidikan, 6(1), 92-101. Google Scholar

Sukmadinata. S. (2019). Pengembangan Kurikulum. Bandung: Remaja Rosdakary.

Sutrisno, Edi. (2013). Manajemen sumber daya manusia. Google Scholar

Uswatun Khasanah, Henry Sudiyanto, Fitria Wahyu Ariyanti, \& Atikah Fatmawati. (2017). Faktor yang Berhubungan dengan Kelulusan Uji Kompetensi Mahasiswa S1 Keperawatan di Stikes Majapahit mojokerto. 182-192. Google Scholar

\section{Copyright holder :}

Andro Ruben Runtu, Fientje J.A. Oentoe, Herry Sumual, Beatrix J. Podung (2022)

First publication right :

Journal of Social Science

This article is licensed under:

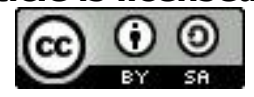

